\title{
Macrophages as target cells for Mayaro virus infection: involvement of reactive oxygen species in the inflammatory response during virus replication
}

\author{
MARIANA G. CAVALHEIRO ${ }^{1 *}$, LEANDRO SILVA DA COSTA ${ }^{1 *}$, HOLMES S. CAMPOS ${ }^{1}$, \\ LETÍCIA S. ALVES ${ }^{2}$, IRANAIA ASSUNÇÃO-MIRANDA ${ }^{2}$ and ANDREA T. DA POIAN ${ }^{1}$ \\ ${ }^{1}$ Instituto de Bioquímica Médica Leopoldo de Meis, Universidade Federal do Rio de Janeiro, Av. \\ Carlos Chagas Filho, 373, Bloco E, Sala 18, 21941-902 Rio de Janeiro, RJ Brasil \\ ${ }^{2}$ Instituto de Microbiologia Paulo de Góes, Universidade Federal do Rio de Janeiro, Av. Carlos \\ Chagas Filho, 373, Bloco I, Sala I0-55, 21941-902 Rio de Janeiro, RJ, Brasil
}

Manuscript received on September 29, 2015; accepted for publication on March 18, 2016

\begin{abstract}
Alphaviruses among the viruses that cause arthritis, consisting in a public health problem worldwide by causing localized outbreaks, as well as large epidemics in humans. Interestingly, while the Old World alphaviruses are arthritogenic, the New World alphaviruses cause encephalitis. One exception is Mayaro virus (MAYV), which circulates exclusively in South America but causes arthralgia and is phylogenetically related to the Old World alphaviruses. Although MAYV-induced arthritis in humans is well documented, the molecular and cellular factors that contribute to its pathogenesis are completely unknown. In this study, we demonstrated for the first time that macrophages, key players in arthritis development, are target cells for MAYV infection, which leads to cell death through apoptosis. We showed that MAYV replication in macrophage induced the expression of TNF, a cytokine that would contribute to pathogenesis of MAYV fever, since TNF promotes an inflammatory profile characteristic of arthritis. We also found a significant increase in the production of reactive oxygen species (ROS) at early times of infection, which coincides with the peak of virus replication and precedes TNF secretion. Treatment of the cells with antioxidant agents just after infection completely abolished TNF secretion, indicating an involvement of ROS in inflammation induced during MAYV infection.
\end{abstract}

Key words: alphaviruses, Mayaro virus, macrophage activation, reactive oxygen species, viral arthritis.

\section{INTRODUCTION}

Viral arthritides are usually acute diseases that in some cases may progress to incapacitating and long lasting arthropathies. Among the viruses that cause arthritis, some members of the Alphavirus genus of the Togaviridae family are of special interest since

Correspondence to: Andrea T. Da Poian

E-mail: dapoian@bioqmed.ufrj.br

*The authors contributed equally to this work their infection rates are increasing worldwide, leading to widespread outbreaks of acute or chronic polyarthritis (Suhrbier et al. 2012, AssunçãoMiranda et al. 2013). Alphaviruses are enveloped single-stranded positive-sense RNA viruses, transmitted to humans by infected mosquitoes. Climate changes and globalization of trade and travels are impacting in the geographic distribution of the alphaviruses, which were restricted to 
specific areas in the past, but are becoming a worldwide problem nowadays (Suhrbier et al. 2012). A recent example is the Chikungunya virus (CHIKV) epidemics in Americas. This virus was responsible for outbreaks in Africa and Asia, but reached Caribbean countries in 2013 (Mowatt and Jackson 2014). In the end of 2014, the first cases were reported in Brazil (http://portalsaude. saude.gov.br/), where the increasing number of autochthonous transmissions points CHIKV epidemics as a potential threat.

The symptoms caused by alphaviruses infection have been related to their geographical distribution, with the Old World viruses, such as CHIKV, Sindbis virus (SINV) and Ross River virus (RRV), causing rash and arthritis, and the New World viruses, such as Venezuelan, Eastern and Western Equine Encephalitis viruses causing encephalitis (Suhrbier et al. 2012). Interestingly, one exception is Mayaro virus (MAYV), which circulates exclusively in South America but causes arthralgia and clusters in phylogenetic analyses with the Old World alphaviruses (Lavergne et al. 2006).

MAYV was firstly isolated in Trinidad, in 1954 (Anderson et al. 1957), being then identified in different countries of the tropical South America (Talarmin et al. 1998, Torres et al. 2004, Forshey et al. 2010, Halsey et al. 2013). Since 1955, when the first case of MAYV infection was reported in Brazil, near the Guamá River in Pará State (Causey and Maroja 1957), several MAYV fever outbreaks have been reported in different Brazilian States, including Pará (Pinheiro et al. 1981, Azevedo et al. 2009), Amazonas (De Figueiredo et al. 2004, Abad-Franch et al. 2012, Mourão et al. 2012), Acre (Tavares-Neto et al. 2004, Silva-Nunes et al. 2006) and Mato Grosso (Zuchi et al. 2014). Most of the cases were described in rural regions, in which MAYV seems to be transmitted by Haemagogus spp. mosquitoes (Hoch et al. 1981), but evidence of MAYV potential transmission by Aedes aegypti
(Long et al. 2011) represent a risk of initiating an urban transmission cycle with a great increase of human exposure to the virus. Nevertheless, the number of cases is certainly underestimated due to the overlapping of symptoms with other febrile arboviroses, such as dengue fever, and the lack of a differential laboratory diagnosis (Figueiredo and Figueiredo 2014, Mourão et al. 2015, Terzian et al. 2015, Vieira et al. 2015).

MAYV-induced disease presents low mortality but shows a high incidence of rheumatic complications, such as myalgia and polyarthralgia (Halsey et al. 2013). The illness begins with an undifferentiated fever, headache, retro-orbital pain, rash and vomiting with 2 to 5 days of duration and a short period of viremia (Pinheiro et al. 1981). Muscle and articular pain reaches several joints, persisting for weeks or months (Hassing et al. 2010, Receveur et al. 2010, Theilacker et al. 2013, Slegers et al. 2014) with small joints preferentially affected (Friedrich-Jänicke et al. 2014).

Most of the knowledge about the molecular and cellular mechanisms involved in alphavirusinduced arthritis comes from studies with RRV and CHIKV. In vitro studies demonstrated that RRV, CHIKV and SINV are able to replicate in macrophage, inducing pro-inflammatory cytokines secretion (Assunção-Miranda et al. 2010, Lidbury et al. 2011, Kumar et al. 2012). Mouse models of CHIKV and RRV infection demonstrated that the articular damage was associated mainly to macrophage infiltration and secretion of proinflammatory mediators (Morrison et al. 2006, Morrison et al. 2011 Chen et al. 2014). Additionally, macrophage depletion or blockage of macrophage differentiation resulted in joint lesions of lesser extension (Morrison et al. 2006, Stoermer et al. 2012). Taken together, these observations point macrophages as important players in the disease. Although arthralgia is a hallmark of MAYV infection (Halsey et al. 2013), particularities and similarities between MAYV infection and CHIKV- 
or RRV-induced arthritis had not been determined to date. In this work we investigated the ability of MAYV to replicate in macrophages and to induce inflammatory responses and cell death. We used SINV as a comparative alphavirus for which macrophage tropism has been previously described (Assunção-Miranda et al. 2010).

\section{MATERIALS AND METHODS}

\section{Cell Culture and Virus PROPAGation}

RAW 264.7, a mouse leukaemic macrophage cell line, and J774, a mouse reticulum sarcoma cell line, were maintained in RPMI-1640 medium (LGC) supplemented with 10\% fetal bovine serum (FBS; Invitrogen Life Technologies) in a humidified incubator at $37^{\circ} \mathrm{C}$ with $5 \% \mathrm{CO}_{2}$. Mouse peritoneal macrophages were obtained from $\mathrm{C} 57 \mathrm{Bl} / 6$ animals by the intraperitoneal injection of $1 \mathrm{~mL}$ of sterile $3 \%$ thioglycollate. After $96 \mathrm{~h}$, the peritoneal macrophages were harvested, washed with RPMI and centrifuged at 1,500 rpm for five minutes. Then, the macrophages were plated at a density of $2 \times 10^{6}$ cells/well in a 6-well plate with RPMI1640 supplemented with $10 \%$ FBS and incubated at $37^{\circ} \mathrm{C}$ with $5 \% \mathrm{CO}_{2}$. After $24 \mathrm{~h}$, the plates were washed with RPMI to remove non-adherent cells before the assays. The procedures were performed according to guidelines of the Institutional Animal Welfare Committee.

MAYV (ATCC VR 66, strain TR 4675) and SINV (AR339) were propagated in BHK-21 cells grown in $\alpha$-Minimum Essential Medium ( $\alpha$-MEM; Invitrogen Life Technologies) supplemented with $10 \%$ FBS. The cells were infected with a multiplicity of infection (MOI) of 0.1 . After $16 \mathrm{~h}$ for SINV and $30 \mathrm{~h}$ for MAYV, the culture media were harvested and cell debris were removed by centrifugation at $2,000 \mathrm{x}$ g for $10 \mathrm{~min}$ and the supernatant was stored at $-80^{\circ} \mathrm{C}$. Virus stocks titers were determined by plaque assay in BHK-21 cells.

\section{MACROPHAGE INFECTION ASSAYS}

Cells were incubated with MAYV or SINV at a MOI of 1 (for RAW 264.7 and J774) or 5 (for primary peritoneal macrophages), for $1 \mathrm{~h}$ at $37^{\circ} \mathrm{C}$ in $5 \% \mathrm{CO}_{2}$. Then, the medium containing the nonadsorbed virus was removed, the cells were washed with serum-free medium and cultured in RPMI supplemented with $5 \% \mathrm{FBS}$, at $37^{\circ} \mathrm{C}$ in $5 \% \mathrm{CO}_{2}$. After the desired periods of infection, conditioned media were collected for virus titration, LDH assay and cytokine quantification. Cellular extracts were used for MTT and flow cytometry assays. Virus inactivated by heating at $65^{\circ} \mathrm{C}$ for $30 \mathrm{~min}$ was used as control. In some experiments, cells were treated with 10 mM N-acetyl-L-cysteine (NAC; SigmaAldrich) or $50 \mu \mathrm{M}$ apocynin (Sigma-Aldrich) for $15 \mathrm{~h}$ after infection with MAYV.

\section{VIRUS TITRATION BY PLAQUE ASSAY}

BHK-21 cells were seeded at $1.25 \times 10^{5}$ cells perwell in 12 -wells plates and incubated at $37^{\circ} \mathrm{C}$ overnight. Ten-fold serial dilutions of the virus samples were prepared in $\alpha$-MEM and incubated with the cells for $1 \mathrm{~h}$ at $37^{\circ} \mathrm{C}(0.2 \mathrm{~mL}$ per well). After $1 \mathrm{~h}$ adsorption, $2 \mathrm{~mL}$ of $1 \%$ carboxymethylcellulose (w/v) (SigmaAldrich) in $\alpha$-MEM supplemented with $2 \%$ FBS were layered onto the infected monolayers and the cells were incubated at $37^{\circ} \mathrm{C}$ for $30 \mathrm{~h}$ or $48 \mathrm{~h}$, for SINV or MAYV, respectively. Plaques were visualized by staining the monolayer with $1 \mathrm{~mL}$ $1 \%$ crystal violet in $20 \%$ ethanol.

\section{CELl Viability ASSAYS}

Determination of macrophage viability during infection was assessed by 3-(4,5-dimethylthiazol2-yl)-2,5-diphenyltetrazolium bromide (MTT) or lactate dehydrogenase (LDH) release assays. For the MTT assay, cells were incubated with 0.5 $\mathrm{mL} 0.5 \mathrm{mg} / \mathrm{mL}$ MTT (USB Corporation) in PBS solution for $90 \mathrm{~min}$ at $37^{\circ} \mathrm{C}$. Then, unreacted dye was discarded and formazan crystals were 
solubilized in $0.04 \mathrm{M} \mathrm{HCl}$ solution in isopropanol (1 mL per well). The absorbance of samples was measured at $570 \mathrm{~nm}$ and $650 \mathrm{~nm}$ for background correction. Lactate dehydrogenase (LDH) release from infected macrophages was determined by using an LDH detection kit (Promega CytoTox 96 assay kit). The procedures were performed according to manufacturer's instructions.

\section{QUANTITATION OF INFECTED CELLS BY FLOW CYTOMETRY}

Flow cytometry analysis was performed to assess the frequency of MAYV- or SINV-infected cells by detecting intracellular viral antigens. After the desired periods of infection, cells were washed with PBS, detached by scraping, harvested and fixed in 4\% formaldehyde in PBS at room temperature for 15 min. After washing, cells were permeabilized with $0.1 \%$ saponin in PBS and incubated with blocking solution (PBS supplemented with 2\% FBS and $0.1 \%$ bovine serum albumin) for $20 \mathrm{~min}$, at room temperature. Then, cells were incubated for $1 \mathrm{~h}$ with mouse anti-Eastern Equine Encephalitis virus monoclonal antibody (Chemicon International, Millipore), which reacts with an E1 epitope shared by all alphaviruses. Then, cells were washed and stained with anti-mouse IgG conjugated to Alexa Fluor 488 (Invitrogen) for $30 \mathrm{~min}$. The percentage of infected cells was analyzed by FACScan Flow Cytometer and CellQuest software (Bectan Dickinson).

CHARACTERIZATION OF CELL DEATH

Apoptosis/necrosis after infection was quantified by a double staining method using The Vybrant Apoptosis Assay Kit\#2 (Molecular Probes). After the infection period, RAW 264.7 cells were washed with PBS, detached by scraping, harvested and stained with Annexin V Alexa Fluor $488(0.5 \mu \mathrm{g} /$ $\mathrm{mL}$ ) and propidium iodide (PI, $0.25 \mu \mathrm{g} / \mathrm{mL}$ ). To further characterize MAYV-induced cell death, the activity of caspases 3 and 7 were measured using the
Muse ${ }^{\mathrm{TM}}$ Caspase-3/7 Kit (Millipore) adapted to flow cytometry. Cells were washed with PBS, detached by scraping, harvested and incubated with Muse ${ }^{\mathrm{TM}}$ Caspase-3/7 Reagent 1:8 and Muse ${ }^{\mathrm{TM}}$ Caspase 7-AAD, according to the manufacturer's protocol. For both assays, the percentage of apoptotic and necrotic cells were analyzed by FACScan Flow Cytometer using the CellQuest software (Bectan Dickinson). UV radiated cells and cells subjected to a freeze-thaw procedure were used as controls.

QUANTITATION OF REACTIVE OXYGEN SPECIES (ROS)

The amount of intracellular reactive oxygen species (ROS) was measured by the formation of the oxidized derivative of 5-(and 6-)-chloromethyl2',7'-dichlorodihydrofluorescein diacetate (DCF, Molecular Probes). After $15 \mathrm{~h}$ of infection with MAYV, adherent cells were washed with PBS and incubated with DCF $0.5 \mu \mathrm{M}$ for 45 minutes. Then, the cells were washed again, detached by scraping and harvested and analyzed by FACScan Flow Cytometer using the CellQuest software (Bectan Dickinson).

\section{QUANTITATION OF CYTOKINES}

The concentrations of cytokines in the conditioned medium of macrophage cultures were determined by ELISA. TNF concentration was quantified using the Standard ELISA Development kit (PeproTech), according to the manufacturer's protocol.

\section{STATISTICAL ANALYSES}

Statistical analyses were performed using Graphpad Prism software (GraphPad software). The results are expressed as mean \pm standard error (SEM). Comparison among sample groups was performed by paired and unpaired Student's tests. Differences were considered statistically significant when $\mathrm{p}<$ 0.05 . Sample size was provided in the respective figure legends. 


\section{RESULTS}

\section{MACROPHAGESARETARGETCELLSFORMAYVREPLICATION}

Previous reports have demonstrated that macrophages are important target cells for alphaviruses' replication (Assunção-Miranda et al. 2010, Lidbury et al. 2011, Kumar et al. 2012), but target cells for MAYV had not been determined so far. In order to investigate MAYV tropism to macrophages, we quantified the release of infectious viral particles over time after infection in the conditioned medium of two murine macrophage lines, RAW 264.7 and J774 (Figs. 1a and b, respectively). We used SINV as control of an arthritogenic alphavirus known to replicate in macrophages (Assunção-Miranda et al. 2010). MAYV replication was observed in both cells, resulting in an increase in viral titers in at least two orders of magnitude. MAYV and SINV present a similar replication profile in both cells, reaching a peak of replication $15 \mathrm{~h}$ after infection, although in RAW 264.7 cells MAYV titers were slightly higher than those obtained for SINV in earlier periods of infection, while SINV titers were one order of magnitude higher than MAYV titers obtained in J774 cells (Figs. 1a, b). Since the results using RAW 264.7 and J774 were very similar, we performed subsequent experiments only in RAW 264.7 macrophages. Flow cytometry experiments confirmed the efficiency and the similar replication profile in RAW 264.7 macrophages for MAYV and SINV, with $67.8 \%$ and $81.2 \%$ of positive cells at 15 $\mathrm{h}$ post-infection, respectively (Figs. 1c, d).

To determine whether virus replication modulates macrophage survival, we investigated macrophage viability during the time course of infection using MTT and LDH release assays. No differences were observed in early stages of MAYV infection when compared to control cells both by MTT and LDH release assays. However, a fast loss of cellular metabolic function was observed as infection progresses, with $46 \%$ and $60 \%$ decrease of viable cells after 15 and $24 \mathrm{~h}$, respectively (Fig. 1e). LDH release assay confirmed the rapid decrease in cell viability during MAYV infection, with loss of membrane integrity in $61 \%$ and $79 \%$ cells after 15 or $24 \mathrm{~h}$ of infection, respectively (Fig. 1f). SINV effects on cell viability were slightly less pronounced (not shown).

In order to investigate whether MAYV tropism to macrophage with the subsequent virusinduced cell death was a phenomenon restricted to the cell lines, we evaluated MAYV infection in murine peritoneal primary macrophages. During the first hours of infection, virus titers measured in the culture medium increased at least one order of magnitude, confirming virus replication also in primary cells (Fig. 2a). MAYV replication showed the same time course profile in primary macrophages as that observed for RAW 264.7 and J774 cells, although the titers reached were lower. Additionally, virus replication in primary macrophages resulted in cell death measured both by MTT or LDH assays (Fig. 2b, c).

\section{MAYV INFECTION INDUCES MACROFAGE APOPTOSIS}

Viral replication may induce cell death through different pathways such as apoptosis, necrosis or autophagy. In the case of the arthritogenic alphaviruses, cell death is commonly associated with activation of the apoptotic machinery and seems to be related to the inflammatory response (Krejbich-Trotot et al. 2011, Assunção-Miranda et al. 2013, Chen et al. 2014, Poo et al. 2014).

The high levels of $\mathrm{LDH}$ released from MAYV-infected cells suggest a necrotic or lateapoptotic cell death induced by infection. To test this hypothesis, we performed flow cytometry analyses of cells labeled with Annexin V (marker of apoptosis) and PI (marker of necrosis) (Figs. $3 a, b)$. The results indicate that MAYV-induced cell death occurs mainly through apoptosis, with almost $30 \%$ of cells labeled only with Annexin V 
a

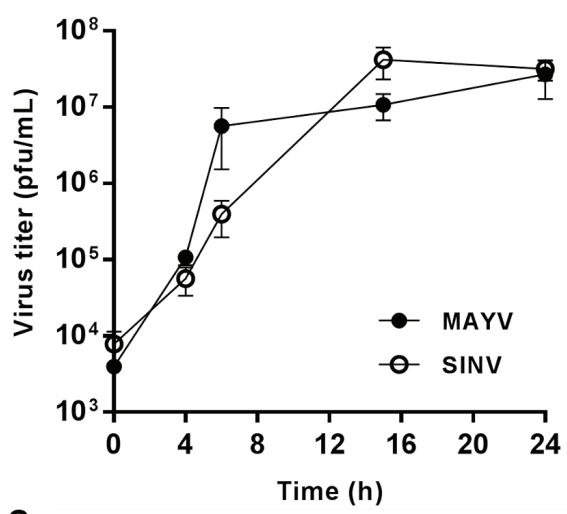

C

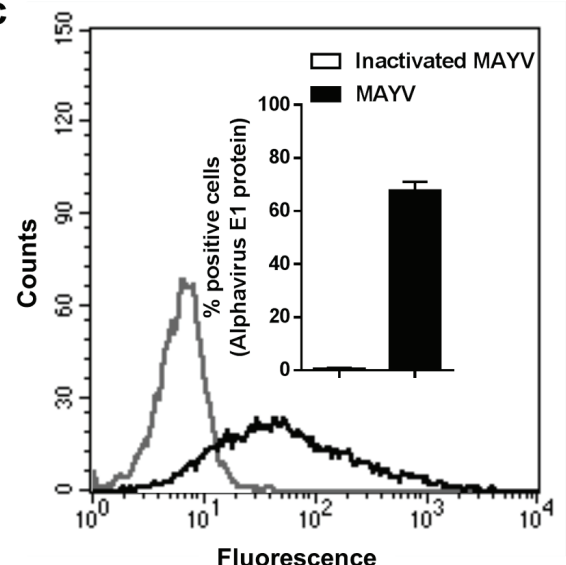

e

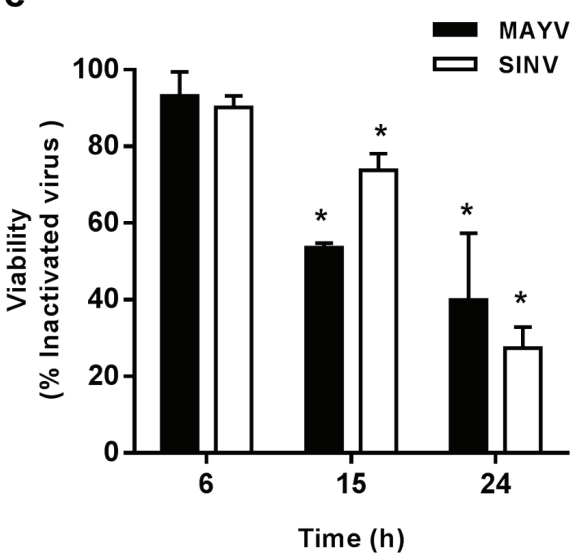

b

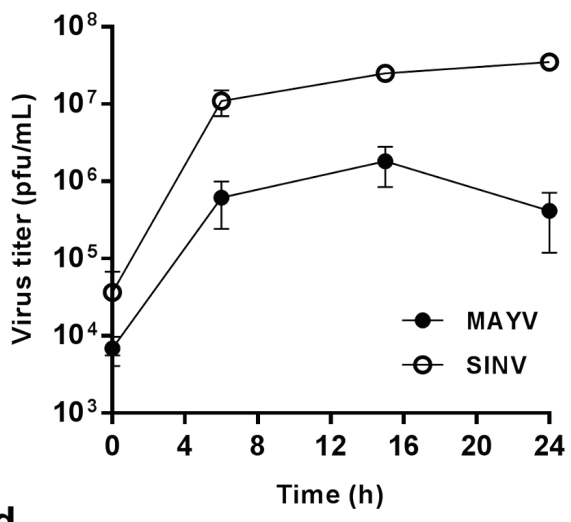

d
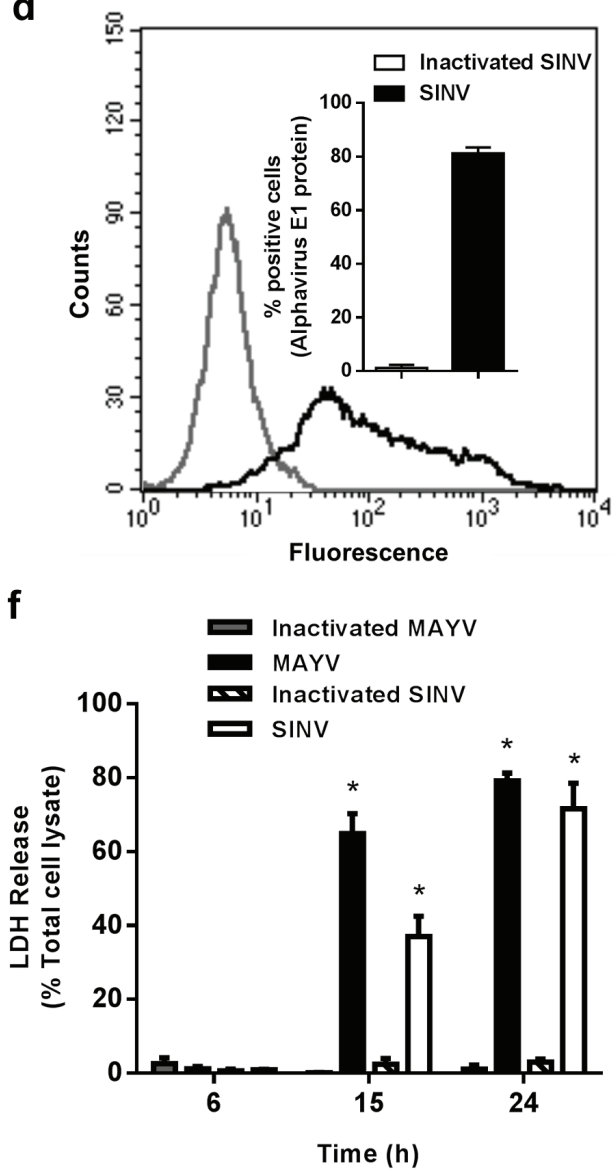

Figure 1 - Characterization of MAYV and SINV replication in macrophages cell lineages. RAW 264.7 (a) and J774 (b) cells were infected with MAYV (filled symbols) or SINV (open symbols) at MOI 1. At different times after infection, virus titer was quantified in the conditioned medium by plaque assay. The efficiency of RAW 264.7 cells infection with MAYV (c) or SINV (d) after $15 \mathrm{~h}$ was evaluated by quantifying the intracellular expression of a conserved alphavirus E1 epitope using flow cytometry. The figures show representative results, with the average \pm SEM plotted in the insets. Viability of RAW 264.7 cells during infection with MAYV (black bars) or SINV (white bars) was evaluated by MTT (e) and LDH release (f) assays. The results obtained for cells incubated with the inactivated virus were used as control for MTT experiments. Values represent the mean \pm SEM of at least three independents experiments. ${ }^{*} p<0.05$. 
a

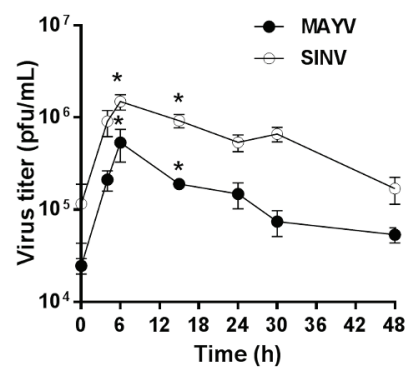

b

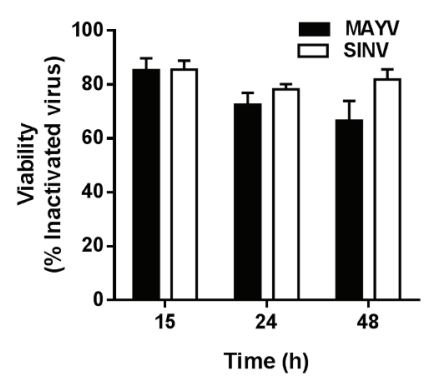

C

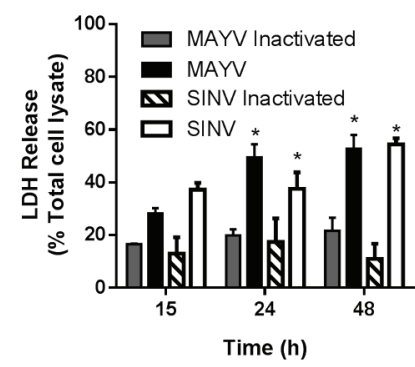

Figure 2 - Replication of MAYV and SINV in primary macrophages. Mouse peritoneal macrophages were isolated and infected with MAYV (filled symbols) or SINV (open symbols) at MOI 5. At different times after infection, virus titer was quantified in the conditioned medium by plaque assay (a). Cell viability during infection was evaluated by MTT (b) and LDH release (c) assays. The results obtained for cells incubated with the inactivated virus were used as control for MTT experiments. Values represent the mean \pm SEM of at least six independents experiments. ${ }^{*} p<0.05$.

and about $30 \%$ of double labeled cells after $15 \mathrm{~h}$ of infection, a pattern similar to that observed for UV-irradiated cells, a control of apoptosis (Fig. 3b). Only a small number of cells were labeled exclusively by PI, suggesting that MAYV-induced necrosis is negligible. Since double labeling with Annexin V and PI does not discriminate between necrotic or late apoptotic cells, we also measured caspase $3 / 7$ activity by flow cytometry (Figs. 3c, d). The results confirmed cell death $15 \mathrm{~h}$ after MAYV infection occurs through apoptosis (Fig. 3d). Cell death is dependent on virus entry and replication since the effects were much less pronounced when the cells were incubated with the inactivated virus (data not shown).

\section{MAYV INFECTION INDUCES TNF SECRETION BY MACROPHAGES}

Proinflammatory cytokines and chemokines are involved in development and progression of joint pathologies in alphavirus infections (AssunçãoMiranda et al. 2010). In this context, macrophages activation would contribute to MAYV-induced inflammation in target tissues. Since TNF, IL-6, IL8 , RANTES and IL-1 $\beta$ were described as important inflammatory mediators in the arthritis induced by CHIKV and RRV (Assunção-Miranda et al. 2013), we measured these cytokines in the conditioned medium of RAW 264.7 cells during the time course of MAYV infection.

TNF secretion was induced in late time points of MAYV infection, with a significant increase in TNF release observed only $15 \mathrm{~h}$ after infection, while TNF levels in the conditioned medium at 6 $\mathrm{h}$ post-infection or when the cells were incubated with the inactivated virus were similar of that observed for the uninfected cells (Fig. 4a). Similar results were found for SINV infection, except that at 24 post-infection, when almost all of the MAYV-infected cells were dead, SINV-infected cells were still secreting high levels of TNF (Fig. $4 \mathrm{~b})$. Induction of TNF secretion was also observed after infection of primary macrophages with MAYV or SINV (Figs. 4c, d). Similarly to RAW 264.7 cells infection, increase of TNF levels occurs concomitantly to cell death. Curiously, secretion of IL-6, RANTES and KC (the IL-8 homologue in mice) were not induced by MAYV infection in RAW 264.7 cells, although a positive response was obtained when the cells were stimulated with polyIC or LPS (data not shown).

\section{MAYV-INDUCED TNF RELEASE IS DEPENDET IN ROS PRODUCTION}

During viral infection, activated macrophages may produce, besides cytokines, reactive oxygen species (ROS), which would be involved in the control 
a

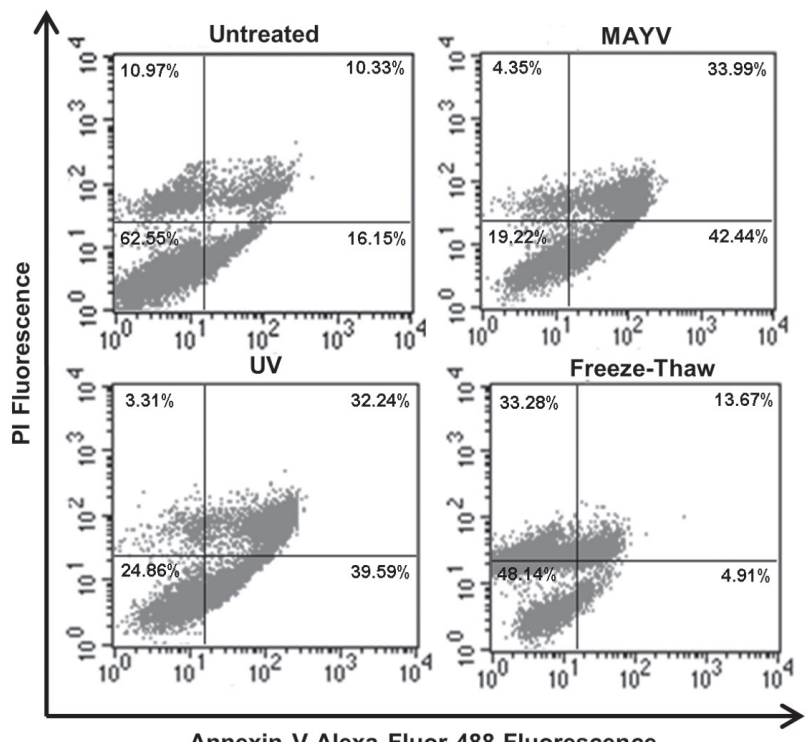

C

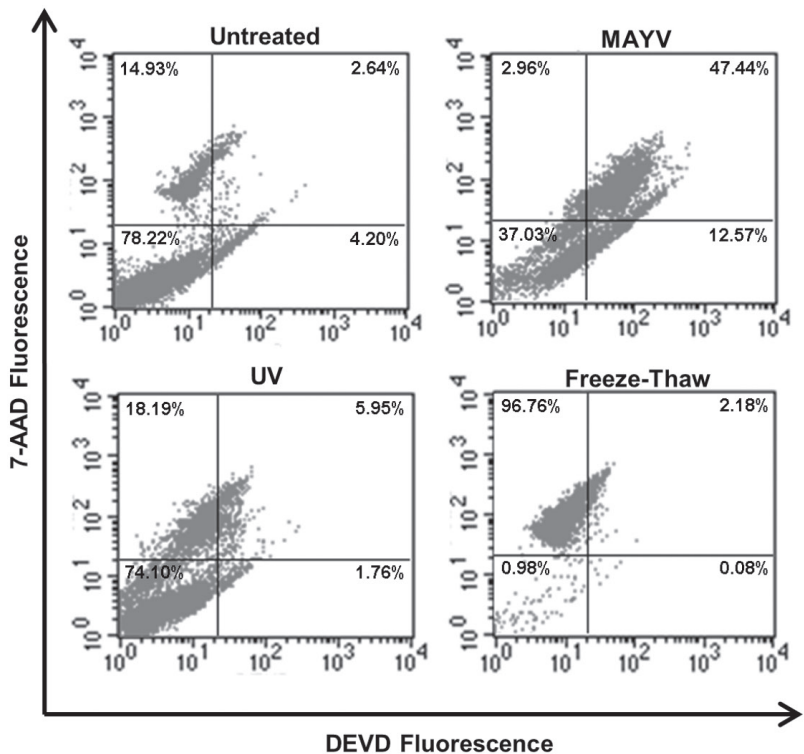

b

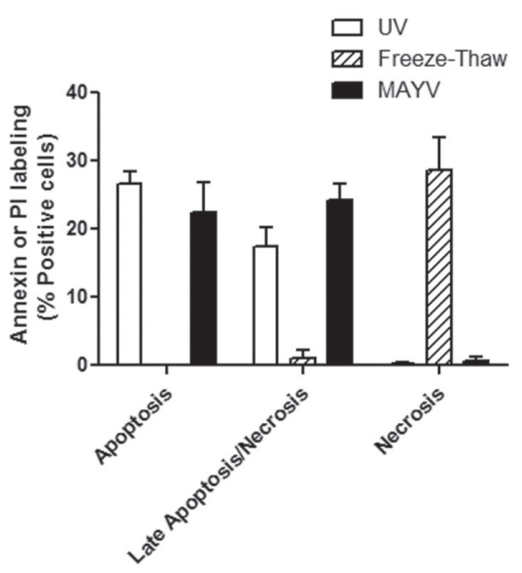

d

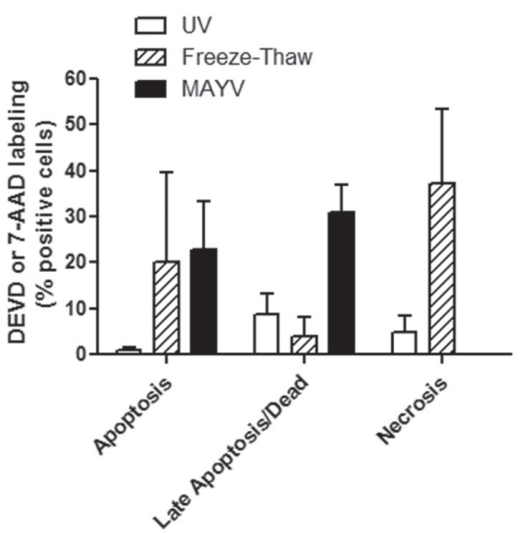

Figure 3 - MAYV-induced RAW 264.7 cell death. RAW 264.7 cells were infected with MAYV for $15 \mathrm{~h}$, stained with Annexin V-Alexa Fluor 488 and PI (a and b) or with Caspase-3/7 kit (c and d), and analyzed by flow cytometry. Representative dot plots are shown in $\mathbf{a}$ and $\mathbf{c}$ with the percentage of viable, necrotic, early apoptotic and late apoptotic/necrotic cells displayed in the lower left, upper left, lower right and upper right quadrants, respectively. The average values of early apoptotic, late apoptotic/necrotic and necrotic cells after $15 \mathrm{~h}$ infection with MAYV are shown in $\mathbf{b}$ and $\mathbf{d}$. The values represent the mean \pm SEM of at least three independents experiments. ${ }^{*} p<0.05$. 
a

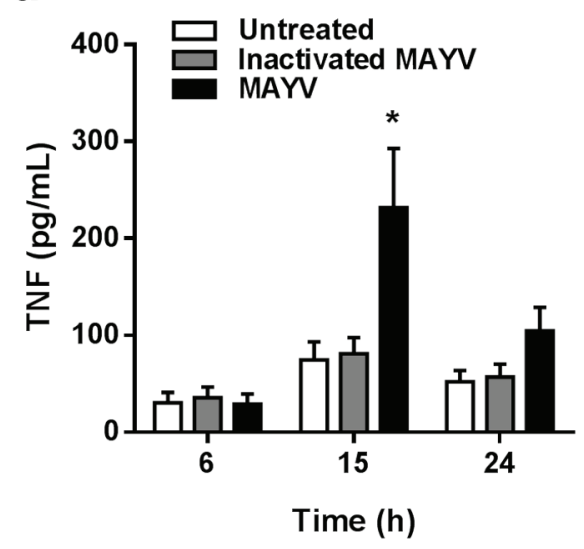

C

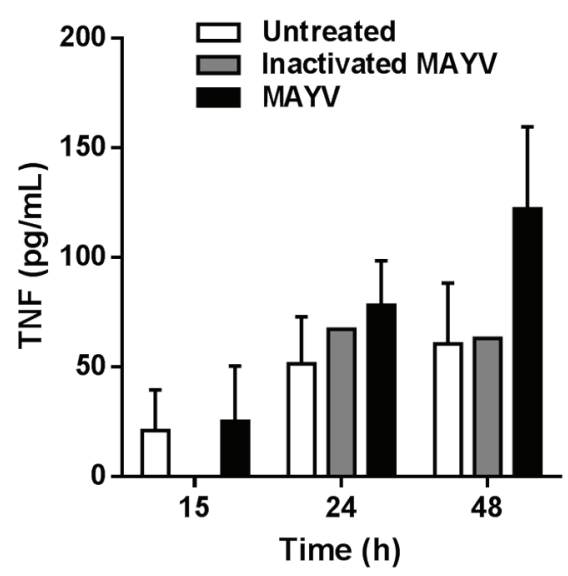

b

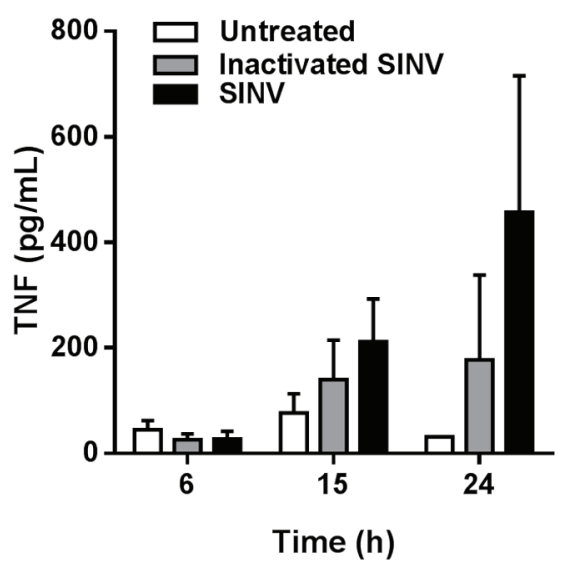

d

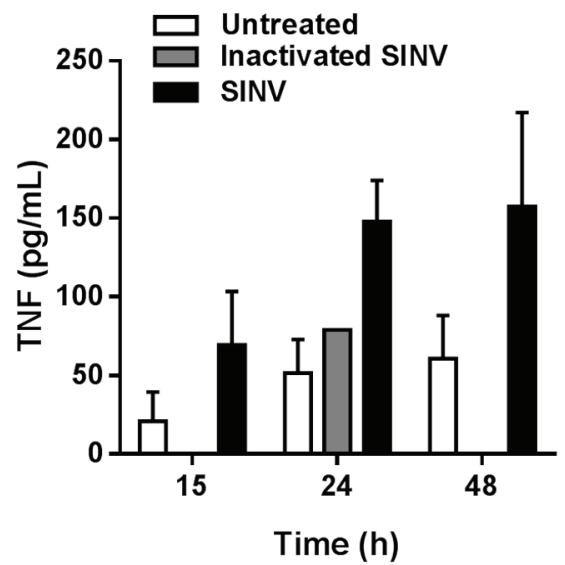

Figure 4 - TNF secretion during MAYV infection. TNF concentrations in the conditioned medium of RAW 264.7 infected with MAYV (a) or SINV (b) at MOI 1 or incubated with the heatinactivated viruses for 6,15 and $24 \mathrm{~h}$ were determined by ELISA. The same procedure was used for mouse peritoneal macrophages infected with MAYV (c) or SINV (d) at MOI 5 or incubated with the heat-inactivated viruses for 15, 24 and $48 \mathrm{~h}$. Values represent mean \pm SEM of at least three independent experiments. ${ }^{*} p<0.05$.

of virus replication, damage in target tissues as well as in cell death induced by virus (Reshi et al. 2014). Thus, we evaluated ROS production during MAYV infection of RAW 264.7 cells. MAYV induces a progressive increase in ROS generation in the early times of infection (6 h; Fig. 5a), a time point of intense virus replication but before the peak of TNF production and cell death. In an attempt to investigate the role of ROS in virusinduced TNF production, we treated RAW 264.7 with the antioxidant agents apocynin and NAC just after the viral adsorption period. Apocynin acts by inhibiting superoxide production by NADPH oxidase, while NAC increases the cellular pools of ROS scavengers. Treatment with both antioxidants reduced TNF release by the infected cells to basal levels (Fig. 5b), indicating an involvement of ROS signaling in macrophage release of inflammatory cytokines during MAYV infection. On the other hand, no effect on MAYV replication and cell 
a

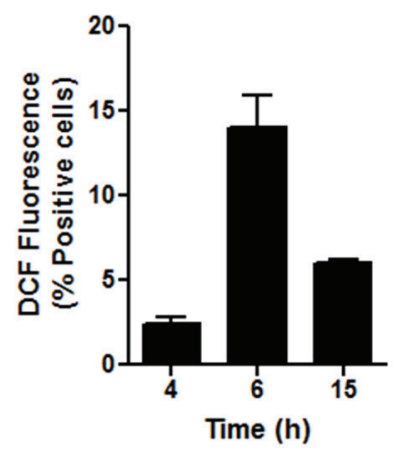

C

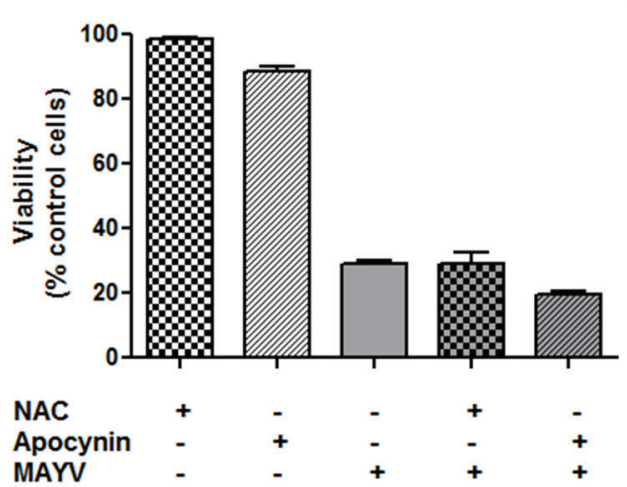

b

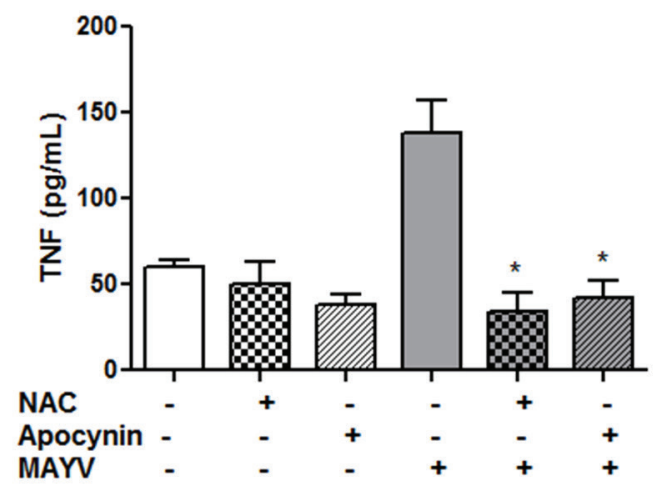

d

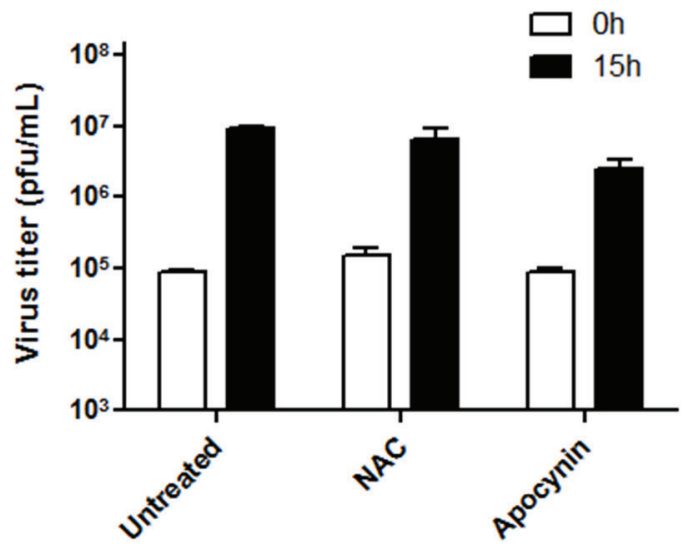

Figure 5 - ROS production during MAYV infection and its effects on cytokine production, cell viability and virus replication. RAW 264.7 cells were infected with MAYV at MOI 1 and ROS production was evaluated by staining the cells with DCF after the indicated times of infection and analyzing the samples by flow cytometry (a). Uninfected cells labeled with DCF were used as control. The role of ROS in cytokine production, cell viability and virus replication was evaluated by treating the cells with NAC $(10 \mathrm{mM})$ or Apocynin $(50 \mu \mathrm{M})$ just after infection and after $15 \mathrm{~h}$ measuring TNF concentrations in the conditioned medium by ELISA (b), determining cell viability by MTT assay (c), and quantifying infectious viral particle production by plaque assay (d). Uninfected cells were used as control for MTT experiments. The values represent the mean \pm SEM of at least three independents experiments. $* p<0.05$.

survival was observed $15 \mathrm{~h}$ post-infection after anti-oxidant treatment (Figs. 5c, d).

\section{DISCUSSION}

The literature on MAYV is scarce, especially regarding the molecular mechanisms of MAYVinduced arthritis and its persistence, which are completely unknown. The studies are almost completely restricted to clinical data, which show that, similarly to what is observed in the infection with Old World alphaviruses, MAYV-infected patients presented a high prevalence of arthralgia (Azevedo et al. 2009, Mourão et al. 2012, Pinheiro et al. 1981), diffuse myalgia (Vieira et al. 2015, Theilacker et al. 2013), highly painful swelling of small finger joints (Friedrich-Jänicke et al. 2014) and polyarthralgia of the hands, wrists, elbows and ankles (Slegers et al. 2014).

Here we demonstrated for the first time that macrophages, cells with an important role in arthritis development, are target cells for MAYV 
replication. Replication curves of MAYV in RAW and J774 macrophage cell lineages were similar to those obtained for SINV, for which macrophage susceptibility has been previously demonstrated (Assunção-Miranda et al. 2010). MAYV was also able to replicate in primary macrophages, although with a smaller titers when compared to the macrophage lineages.

Macrophages are specialized innate immune cells essential for recognition and elimination of pathogens (Koenderman et al. 2014). The involvement macrophages in the productive replication of other arthritogenic alphaviruses, such as RRV, CHIKV and SINV, has already been demonstrated, and these cells were shown to be among the main cellular components of the inflammatory infiltrate in the injured tissues after alphavirus infection in vivo (Lidbury and Mahalingam 2000, Way et al. 2002, Morrison et al. 2006, Her et al. 2010, Labadie et al. 2010, Kumar et al. 2012). Furthermore, in CHIKV-infected patients, high detection of viral antigens in monocytes correlates with higher virus titers in the blood, as well as persistent infection of synovial macrophages was detected in chronic patients (Her et al. 2010, Hoarau et al. 2010). Additionally, pharmacological depletion of macrophages in mouse models of RRV and CHIKV infection resulted in lesser extent of articular damage, indicating an involvement of these cells in the pathogenesis of the arthritis induced by the alphaviruses (Gardner et al. 2010, Lidbury and Mahalingam 2000).

Our results showed that macrophage infection with MAYV results in cell death through apoptosis after $15 \mathrm{~h}$ of infection. This is in agreement with several reports that have shown that infection with other alphaviruses also induces apoptosis in various cell types in vitro and in vivo ( $\mathrm{Li}$ and Stollar 2004, Krejbich-Trotot et al. 2011, Silva da Costa et al. 2012). The cellular pathways involved in alphavirus-induced apoptosis are complex and remains poorly understood. Nevertheless, apoptosis may be associated to the pathogenesis of alphaviruses infection and its inhibition could be a possible therapeutic strategy to prevent developing disease.

Several studies on alphaviruses-induced arthritis using animal models or patients samples support that the macrophage production of inflammatory mediators, such as TNF, in damaged tissue, contributes to the establishment of the disease (Way et al. 2002, Lidbury et al. 2008, Gardner et al. 2010, Chopra and Venugopalan 2011, Patil et al. 2012, Dhanwani et al. 2014). In agreement to these observations, we showed here that MAYV and SINV replication in RAW and primary macrophages induces TNF release. In the context of infection, TNF can be considered a key cytokine in inflammation since it regulates the expression of prostaglandins, metalloproteinases, adhesion molecules and others pro-inflammatory cytokines in the synovia (Feldmann et al. 2014). Also, TNF produced in MAYV-infected macrophages would contribute to pathogenesis of MAYV fever, since TNF promotes an inflammatory profile characteristic of arthritis.

TNF production by the infected cells may be a result of the viral recognition thought the patternrecognition receptor signaling pathway, which besides cytokines also promotes the generation of other molecules, such as ROS (Ogier-Denis et al. 2008, Soucy-Faulkner et al 2010). Here we found a significant increase in ROS production $6 \mathrm{~h}$ after MAYV infection, which coincides with the peak of virus replication and precedes TNF secretion. In this context, there are evidence in the literature that ROS may be a trigger of the induction of TNF expression (Ogier-Denis et al. 2008, Hu et al. 2011). An example is the case of murine microglia infection with herpes simplex virus 1 in which ROS production by NADPH oxidase mediates TNF and IL-1 $\beta$ production through activating mitogen-activated protein kinases (Hu et al. 2011). Accordingly, we found that treatment of RAW cells 
just after MAYV infection with two antioxidant agents, NAC and apocynin, completely abolished TNF secretion, supporting the involvement of ROS in inflammation induced during MAYV infection. The mechanism by which ROS induces TNF production in the MAYV-infected macrophages still requires further investigation.

Recent studies demonstrated that ROS production during infection by RNA virus such as human immunodeficiency virus, hepatitis $\mathrm{C}$ virus and influenza virus is associated to cell death through apoptosis (Reshi et al. 2014). Additionally, TNF is also a well characterized trigger of programmed cell death (Morgan et al. 2008, Han et al. 2011) and would be involved in MAYV-induced apoptosis. However, macrophage treatment with the antioxidant agents, which besides reducing ROS also blocked TNF production in our model, did not result in an increase in cell viability or a reduction in viral production, indicating that neither the early oxidative stress induced by infection nor the subsequent TNF release are associated with virus-induced macrophage death. In agreement with ours results, CHIKV-induced apoptosis is independent of oxidative stress (Joubert et al. 2012). On the other hand, in contrast to our results, NAC completely abrogates SINV-induced apoptosis of carcinoma and neuroblastoma cells (Lin et al. 1995). It is important to point out that since NAC directly eliminated ROS by increasing the intracellular stores of glutathione (Pinkus et al. 1996) and apocynin acts by inhibiting superoxide production by NADPH oxidase (Vejražka et al. 2005), at this moment we cannot exclude the possibility that mitochondrial ROS might play a role in macrophage apoptosis induced by MAYV infection and this is a perspective for future studies.

Currently, there are no specific vaccines or therapies for the prevention or treatment of arthritis induced by alphaviruses. Therefore, MAYVinduced arthralgia can be disabling and long lasting, promoting social and economic impacts.
The development of therapeutic approaches for MAYV-induced arthritis will only be possible with the understanding of the molecular mechanisms involved in its pathogenesis. The involvement of oxidative stress in tissue damage induced by alphaviruses remains an almost unexplored field. Our data reinforce the importance of this pathway in the inflammatory response induced by MAYV and possibly of other alphavirus, opening new perspectives in the search for therapeutic targets for treatment of arthritis induced by alphavirus.

\section{ACKNOWLEDGMENTS}

The authors thank Rômulo L.S. Neris for help with the experiments using primary macrophages. This work was supported by Conselho Nacional de Desenvolvimento Científico e Tecnológico (CNPq) and Fundação Carlos Chagas Filho de Amparo à Pesquisa do Estado do Rio de Janeiro (FAPERJ).

\section{REFERENCES}

ABAD-FRANCH F, GRIMMER GH, DE PAULA VS, FIGUEIREDO LTM, BRAGA WSM AND LUZ SLB. 2012. Mayaro Virus Infection in Amazonia: A Multimodel Inference Approach to Risk Factor assessment. PLoS Negl Trop Dis 6: 1169-1189.

ANDERSON C, DOWNS WG, WATTLEY GH AND AHIN NW. 1957. Mayaro virus: a new human disease agent. II. Isolation from blood of patients in Trinidad, B.W.I. Am J Trop Med Hyg 6: 1012-1016.

ASSUNCÃO-MIRANDA I, BOZZA MT AND DA POIAN AT. 2010. Proinflammatory response resulting from Sindbis virus infection of human macrophages: implications for the pathogenesis of viral arthritis. J Med Virol 82: 164174.

ASSUNÇÃO-MIRANDA I, CRUZ-OLIVEIRA C AND DA POIAN AT. 2013. Molecular mechanisms involved in the pathogenesis of alphavirus-induced arthritis. Biomed Res Int 2013: Article ID 973516.

AZEVEDO RS, SILVA EV, CARVALHO VL, RODRIGUES SG, NUNES NETO JP AND MONTEIRO H. 2009. Mayaro fever virus. Brazilian Amazon Emerg Infect Dis 15: $1830-1832$.

CAUSEY OR AND MAROJA OM. 1957. Mayaro virus: a new human disease agent. III. Investigation of an epidemic of acute febrile illness on the river Guama in Para, Brazil, 
and isolation of Mayaro virus as causative agent. Am J Trop Med Hyg 6: 1017-1023.

CHEN W et al. 2014. Arthritogenic alphaviral infection perturbs osteoblast function and triggers pathologic bone loss. Proc Natl Acad Sci 111: 6040-6045.

CHOPRA A AND VENUGOPALAN A. 2011. Persistent rheumatic musculoskeletal pain and disorders at one year post-chikungunya epidemic in south Maharashtra - a rural community based observational study with special focus on naïve persistent rheumatic musculoskeletal cases and selected cytokine expression. Indian J Rheumatol 6: 5-11.

DE FIGUEIREDO RM, THATCHER BD, DE LIMA ML, ALMEIDA TC, ALECRIM WD AND GUERRA MV. 2004. Exanthematous diseases and the first epidemic of dengue to occur in Manaus, Amazonas State, Brazil, during 1998-1999. Rev Soc Bras Med Trop 37: 476-479.

DHANWANI R, KHAN M, LOMASH V, RAO PVL, LY H AND PARIDA M. 2014. Characterization of Chikungunya Virus Induced Host Response in a Mouse Model of Viral Myositis. PLoS one 9: e92813.

FELDMANN M, MONACO C, NANCHAHAL J AND TAYLOR P. 2014. Anti-TNF therapy: past, present and future. Int Immunol 27(1): 55-62.

FIGUEIREDO ML AND FIGUEIREDO LT. 2014. Emerging alphaviruses in the Americas: Chikungunya and Mayaro. Rev Soc Bras Med Trop 47(6): 677-683.

FORSHEY BM et al. 2010. NMRCD Febrile Surveillance Working Group: Arboviral etiologies of acute febrile illnesses in Western South America, 2000-2007. PLoS Negl Trop Dis 4: e787.

FRIEDRICH-JÄNICKE B, EMMERICH P, TAPPE D, GÜNTHER S, CADAR D AND SCHMIDT-CHANASIT J. 2014. Genome Analysis of Mayaro Virus Imported to Germany from French Guiana. Emerg Infect Dis 20: 12551257.

GARDNER J, ANRAKU I, LE TT, LARCHER T, MAJOR L, ROQUES P AND SUHRBIER A. 2010. Chikungunya virus arthritis in adult wild-type mice. J Virol 84: 80218032.

HALSEY ES, SILES C, GUEVARA C, VILCARROMERO S, JHONSTON EJ, RAMAL C AND AMPUERO JS. 2013. Mayaro virus infection, Amazon basin region, Peru, 20102013. Emerg Infect Dis 19: 1839-1842.

HAN J, ZHONG C AND ZHANG D. 2011. Programmed necrosis: backup to and competitor with apoptosis in the immune system. Nat Immunol, 12: 1143-1149.

HASSING R, LEPARC-GOFFART I, BLANK S, THEVARAYAN S, TOLOU H, VAN DOORNUM G AND VAN GENDEREN P. 2010. Imported Mayaro virus infection in The Netherlands. J Infect 61: 343-345.

HER Z et al. 2010. Active Infection of Human Blood Monocytes by Chikungunya Virus Triggers an Innate Immune Response. J Immunol 184: 5903-5913.
HOARAU JJ et al. 2010. Persistent Chronic Inflammation and Infection by Chikungunya Arthritogenic Alphavirus in Spite of a Robust Host Immune Response. J Immunoly 184(10): 5914-5927.

HOCH AL, PETERSON NE, LEDUC JW AND PINHEIRO FP. 1981. An outbreak of Mayaro virus disease in Belterra, Brazil. III. Entomological and ecological studies. Am J Trop Med Hyg 30: 689-698.

HU S, SHENG WS, SCHACHTELE SJ AND LOKENSGARD JR. 2011. Reactive oxygen species drive herpes simplex virus (HSV)-1-induced proinflammatory cytokine production by murine microglia. J Neuroinflam 8: 123.

JOUBERT PE, WERNEKE SW, DE LA CALLE C, GUIVELBENHASSINE F, GIODINI A, PEDUTO L, LEVINE B, SCHWARTZ O, LENSCHOW DJ AND ALBERT ML. 2012. Chikungunya virus-induced autophagy delays caspase-dependent cell death. J Exp Med 209(5): 10291047.

KOENDERMAN L, BUURMAN W AND DAHA MR. 2014. The innate immune response. Immunol Lett 162: 95-102.

KREJBICH-TROTOT P, DENIZOT M, HOARAU JJ, JAFFAR-BANDJEE MC, DAS T AND GASQUE P. 2011. Chikungunya virus mobilizes the apoptotic machinery to invade host cell defenses. FASEB J 25(1): 314-325.

KUMAR S, JAFFAR-BANDJEE MC AND GIRY C. 2012. Mouse macrophage innate immune response to Chikungunya virus infection. Virol J 9: 313.

LABADIE K, LARCHER T AND JOUBERT C. 2010. Chikungunya disease in nonhuman primates involves long-term viral persistence in macrophages. J Clin Invest 120: 894-906.

LAVERGNE A, THOISY BD, LACOSTE V, PASCALIS H, POULIQUEN JF, MERCIER V AND KAZANJI M. 2006. Mayaro virus: complete nucleotide sequence and phylogenetic relationships with other alphaviruses. Vir Res 117: 283-290.

LI ML AND STOLLAR V. 2004. Alphaviruses and apoptosis. Int Rev Immunol 23(1-2): 7-24.

LIDBURY BA AND MAHALINGAM S. 2000. Specific ablation of antiviral gene expression in macrophages by antibody-dependent enhancement of Ross River virus infection. J Virol 74: 8376-8381.

LIDBURY BA, RULLI NE, MUSSO CM, COSSETTO SB, ZAID A, SUHRBIER A AND MAHALINGAM S. 2011. Identification and characterization of a ross river virus variant that grows persistently in macrophages, shows altered disease kinetics in a mouse model, and exhibits resistance to type I interferon. J Virol 85: 5651-5663.

LIDBURY BA, RULLI NE AND SUHRBIER A. 2008. Macrophage derived proinflammatory factors contribute to the development of arthritis and myositis after infection with an arthrogenic alphavirus. J Infect Dis 197: 1585-1593.

LIN KI, LEE SH, NARAYANAN R, BARABAN JM, HARDWICK JM AND RATAN RR. 1995. Thiol agents 
and Bcl-2 identify an alphavirus-induced pathway that requires activation of the transcription factor NF- $\kappa \mathrm{B}$. J Cell Biol 131:1149-1161.

LONG KC, ZIEGLER SA, THANGAMANI S, HAUSSER NL AND KOCHEL TJ. 2011. Experimental transmission of Mayaro virus by Aedes aegypti. Am J Trop Med Hyg 85: 750-757.

MORGAN MJ, KIM Y AND LIU Z. 2008. TNF $\alpha$ and reactive oxygen species in necrotic cell death. Cell Res 18: 343349.

MORRISON TE, OKO L AND MONTGOMERY S. 2011. A. A mouse model of Chikungunya virus-induced musculoskeletal inflammatory disease: evidence of arthritis, tenosynovitis, myositis, and persistence. Am J Pathol 178: 32-40.

MORRISON TE, WHITMORE AC, SHABMAN RS, LIDBURY BA, MAHALINGAM S AND HEISE MT. 2006. Characterization of Ross River virus tropism and virus-induced inflammation in a mouse model of viral arthritis and myositis. J Virol 80: 737-749.

MOURÃO MPG, BASTOS MS, DE FIGUEIREDO RP, GIMAQUE JBL, GALUSSO ES, KRAMER VM, DE OLIVEIRA CMC, NAVECA FG AND FIGUEIREDO LTM. 2012. Mayaro Fever in the City of Manaus, Brazil, 2007-2008. Vector Borne Zoonotic Dis 16: 42-46.

MOURÃO MP, BASTOS MS, FIGUEIREDO RM, GIMAQUE JB, ALVES VC, SARAIVA MD, FIGUEIREDO ML, RAMASAWMY R, NOGUEIRA MLAND FIGUEIREDO LT. 2015. Arboviral diseases in the Western Brazilian Amazon: a perspective and analysis from a tertiary health $\&$ research center in Manaus, State of Amazonas. Rev Soc Bras Med Trop 48(1): 20-26

MOWATT L AND JACKSON ST. 2014. Chikungunya in the Caribbean: An Epidemic in the Making. J Infect Dis Ther $1-6$.

OGIER-DENIS E, MKADDEM SB AND VANDEWALLE A. 2008. NOX enzymes and Toll-like receptor signaling. Semin Immunopathol 30(3): 291-300.

PATIL DR, HUNDEKAR SL AND ARANKALLE VA. 2012. Expression profile of immune response genes during acute myopathy induced by chikungunya virus in a mouse model. Microb Infect 14: 457-469.

PINHEIRO FP, FREITAS RB, TRAVASSOS DA ROSA JF, GABBAY YB, MELLO WA AND LE DUC JW. 1981. An Outbreak of Mayaro Virus Disease in Belterra, Brazil: I. Clinical and Virological Findings. Am J Trop Med Hyg 30: 674-681.

PINKUS R, WEINER LM AND DANIEL V. 1996. Role of oxidants and antioxidants in the induction of AP-1, NFkappaB, and glutathione S-transferase gene expression. J Biol Chem 271: 13422-13429.

POO YS, RUDD PA, GARDNER J, WILSON JA, LARCHER T, COLLE MA AND SUHRBIER A. 2014. Multiple
Immune Factors Are Involved in Controlling Acute and Chronic Chikungunya Virus Infection. PLoS Negl Trop Dis 8: e3354.

RECEVEUR M, GRANDADAM M, PISTONE T AND MALVY D. 2010. Infection with Mayaro virus in a French traveller returning from the Amazon region, Brazil, January, 2010. Euro Surveill 15: 19563.

RESHI ML, SU Y AND HONG J. 2014. RNA Viruses: ROSMediated Cell Death. Int J Cell Biol 2014: Article ID 467452.

SILVA DA COSTA L, PEREIRA DA SILVA AP, DA POIAN AT AND EL-BACHA T. 2012. Mitochondrial Bioenergetic Alterations in Mouse Neuroblastoma Cells Infected with Sindbis Virus: Implications to Viral Replication and Neuronal Death. PLoS ONE 7(4): e33871.

SILVA-NUNES M, MALAFRONTE RS, LUZ BA AND SOUZA EA. 2006. The Acre Project: the epidemiology of malaria and arthropodborne virus infections in a rural Amazonian population. Cad Saude Publica 22: 1325-1334.

SLEGERS CAD, KEUTER M, GÜNTHER S, SCHMIDTCHANASIT J, VAN DER VEN AJ AND DE MAST Q. 2014. Persisting arthralgia due to Mayaro virus infection in a traveler from Brazil: Is there a risk for attendants to the 2014 FIFA World Cup? J Clin Virol 60: 317-319.

SOUCY-FAULKNER A, MUKAWERA E, FINK K, MARTEL A, JOUAN L, NZENGUE Y, LAMARRE D, VELDE CV AND GRANDVAUX N. 2010. Requirement of NOX2 and Reactive Oxygen Species for Efficient RIGI-Mediated Antiviral Response through Regulation of MAVS Expression. PLoS Pathogens 6(6): e1000930.

STOERMER KA, BURRACK A, OKO L, MONTGOMERY SA, BORST LB, GILL RG AND MORRISON TE. 2012. Genetic Ablation of Arginase 1 in Macrophages and Neutrophils Enhances Clearance of an Arthritogenic Alphavirus. J Immunol 189(8): 4047-4059.

SUHRBIER A, JAFFAR-BANDJEE MC AND GASQUE P. 2012. Arthritogenic alphaviruses--an overview. Nat Rev Rheumatol 8: 420-429.

TALARMIN A et al. 1998. Mayaro virus fever in French Guiana: isolation, identification, and seroprevalence. Am J Trop Med Hyg 59: 452-456.

TAVARES-NETO J, FREITAS-CARVALHO J, NUNES MR AND ROCHA G. 2004. Serologic survey for yellow fever and other arboviruses among inhabitants of Rio Branco, Brazil, before and three months after receiving the yellow fever 17D vaccine. Rev Soc Bras Med Trop 37: 1-6.

TERZIAN AC et al. 2015. Isolation and characterization of Mayaro virus from a human in Acre, Brazil. Am J Trop Med Hyg 92(2): 401-404.

THEILACKER C, HELD J, ALLERING L, EMMERICH P AND SCHMIDT-CHANASIT J. 2013. Prolonged polyarthralgia in a German traveller with Mayaro virus infection without inflammatory correlates. BMC Infect Dis 13: $369-372$. 
TORRES JR, RUSSELL KL, VASQUEZ C AND BARRERA R. 2004. Family cluster of Mayaro fever, Venezuela. Emerg Infect Dis 10: 1304-1306.

VEJRAŽKA M, MÍČEK R AND ŠTÍPEK S. 2005. Apocynin inhibits NADPH oxidase in phagocytes but stimulates ROS production in non-phagocytic cells. Biochim Biophys Acta 1722: 143-147.

VIEIRA CJ et al. 2015. Detection of Mayaro virus infections during a dengue outbreak in Mato Grosso, Brazil. Acta Trop 147: 12-16.
WAY SRJ, LIDBURY BAAND BANYER JL. 2002. Persistent Ross River Virus Infection of Murine Macrophages: an in Vitro Model for the Study of Viral Relapse and Immune Modulation during Long-Term Infection. Virology 301: 281-292.

ZUCHI N, HEINEN LBS, DOS SANTOS MAM, PEREIRA FC AND SLHESSARENKO RD. 2014. Molecular detection of Mayaro virus during a dengue outbreak in the state of Mato Grosso, Central-West Brazil. Mem Inst Oswaldo Cruz 109: 820-823. 